Research article

\title{
EXPERIMENTAL ASSESSMENT OF A NEW TYPE OF VASCULAR PROSTHESES WITH ADIPONECTIN (ADIPOGRAFT Ra 1vk 7/350) ON SHEEP
}

\author{
PODLAHA Jiřrı ${ }^{*}$, SCHWANHAEUSER Kräuff ${ }^{2}$ \\ ${ }^{1}$ Department of Surgery, University Hospital Brno, Faculty of Medicine, Masaryk University, Brno, \\ Czech Republic; ${ }^{2}$ Department of Preventive Medicine, Faculty of Medicine, Masaryk University, Brno, \\ Czech Republic
}

(Received 29 March; Accepted 09 September 2014)

\begin{abstract}
Despite medical advancements, the development of an ideal vascular prosthesis still poses a great challenge. In this study the researchers tried to test and verify the characteristics of a new type of vascular prosthesis, using adiponectin (Adipograft Ra 1vk 7/350) developed at the Knitting Research Institute, a.s. Brno. Two types of vascular prostheses (12 with adiponectin and 6 as a control without adiponectin) were implanted in nine healthy 4-year-old Merino sheep. The implantation site was the common carotid artery and the length of the implant was $10 \mathrm{~cm}$. We applied the theory of the protected coagulum, whereby all sheep received antibiotics as a prophylactic measure. A Doppler U.S. was performed before finishing each operation, in order to verify the patency of the prostheses. Each animal was followed up during the whole study and the prostheses were extirpated on days 30 and 100 (1 and 3 months). It was observed that all prostheses coated with adiponectin showed patency after extirpation. The lumen implants were of a consistent thickness of $7 \mathrm{~mm}$. Histological study of the implanted prostheses confirmed a quick, high quality, healing. Experimental vascular prostheses coated with adiponectin appeared to be successful in clinical practice. The researchers think that Adipograft $\mathrm{Ra} 1 \mathrm{vk} 7 / 350$ can be a turning point in the development of vascular prostheses, due to its patency and quick healing.
\end{abstract}

Key words: adiponectin, experimental surgery, pre-clinical trial, vascular prosthesis.

\section{INTRODUCTION}

The aim of this experimental animal study was to evaluate, test and verify the characteristics of a new type of vascular prosthesis using adiponectin (Adipograft $\mathrm{Ra} 1 \mathrm{vk} 7 / 350$ ). Adiponectin is a hormone produced by the white adipose tissue and is released directly into the blood, where its levels are within the range $0.5-30 \mu \mathrm{g} / \mathrm{mL}$ with a total concentration of $0.01 \%$ of the total plasma proteins [1]. It belongs to the same group of adipokines as leptin, TNF- $\alpha$, plasminogen activator inhibitor, adipsin

Corresponding author: e-mail: jiri.podlaha@fnbrno.cz 
and resistin [2]. It is a collagen-like protein, which shows similarities with collagen type VIII and X [1].

It is up-regulated by insulin and an insulin-like growth factor; it is down-regulated by obesity and increased secretion of TNF- $\alpha$. Adiponectin acts directly on skeletal muscles and liver, influencing the total concentration of triglycerides. This causes the activation of receptors and kinase enzymes, which thereby activate $\beta$-oxidation and gluconeogenesis. As a result, there is a decrease in the total triglycerides level in the cells and an increase in their sensitivity to insulin [3].

The total level of adiponectin is at a lower level in diabetes mellitus type 2 and atherosclerotic subjects. Obesity and high BMI decrease the synthesis of adiponectin, as well. Low levels of adiponectin increase LDL-cholesterol levels in the blood, which are then transformed by monocytes into foam-cells, which develop atherosclerotic plaques, which thereby damage the vascular endothelium [3]. We have to bear in mind that atherosclerosis is an inflammatory process caused by foam-cell accumulation in the damaged endothelium. [4].

Atherosclerosis was found in patients with low levels of adiponectin in the blood vessels. This caused a reduced ability of the damaged endothelium to repair, and increased the possibility for the formation of atherosclerotic plaques [5].

The accumulated adiponectin in the blood vessel intima, influences the adhesion of expression molecules, such as: VCAM-1 and ICAM-1; and TNF- $\alpha$. This thereby affects the adhesion of monocytes and reduces LDL- microphages uptake and the formation of foam-cells [3].

Another property of adiponectin is its ability to reduce the formation of smooth muscle cells in the injured blood vessel wall. This prevents extreme muscle formation and concomitant narrowing of the lumen. This was for the first time described in adiponectin deficient rats [5].

The usual adiponectin level in obese patients is approximately $3.7 \mu \mathrm{g} / \mathrm{mL}$, while in healthy patients it is around $8.9 \mu \mathrm{g} / \mathrm{mL}$. [4,6]. Adiponectin plasma concentration correlates with HDL and cholesterol levels. The positive association is presumably due to the adiponectin's ability to activate the enzyme lipoprotein lipase $[4,6]$.

The characteristics of adiponectin, which give it a quality of an endothelium protector against atherosclerosis and neovascularisation, are used for the development of a vascular prosthesis coated with this hormone. The adiponectin coating on the inner surface of the vascular prosthesis reduces the formation of the thrombocyte adhesion factor (TNF- $\alpha$ ) and decreases the formation of smooth muscle cells, thereby preventing narrowing of the lumen [5].

It also supports the migration and proliferation of endothelial cells, leading to a faster formation of the neointima, which aids the inhibition of blood clotting in the inner surface of the knitted prosthesis. A quick and intact endothelial layer formation prevents the precipitation of platelets and thereby prevents thrombus formation. 
It is now possible to manufacture adiponectin, by means of DNA recombination, in the form of human or rat adiponectin. E. Coli is employed in its production. The market price of recombinant adiponectin is approximately US $\$ 200$ for $25 \mu \mathrm{g}$.

An important aim, when developing vascular prostheses, is to maximize the period of lumen patency and, at the same time, to increase their functionality and long-term stability. The lumen of the prosthesis must be as smooth as possible, in order to improve patency, while the outer layer surface should be rough, in order to aid healing [7]. In order to avoid thrombosis the flow inside the prosthesis must be laminar, and not turbulent $[8,9]$.

Each vascular prosthesis must comply with the following requirements:

- Surgical acceptance;

- Security;

- Long-term patency.

Adiponectin's characteristics, of protecting the endothelium against atherosclerosis and neovascularisation, were utilized in the development of a prosthesis coated with this hormone. Adiponectin, in certain amounts on the inner site of the prosthesis, accelerates healing.

Adipograft $\operatorname{Ra} 1 \mathrm{vk} 7 / 350^{\circledR}$ vascular prostheses were subjected to biocompatibility tests and they complied with the following requirements: non-toxicity; non-antigenic and non-carcinogenic properties; exhibiting permanent inertness. Tests for possible haemolytic effects, cytotoxicity and pyrogenicity were performed with satisfactory results [10].

Other tests of biocompatibility - such as allergisation, irritability, systemic toxicity, subchronic toxicity, and genotoxicity - were performed with the RaK vascular prosthesis with collagen, which has been manufactured for several years in accordance to the approval No 89/0313/00-IIB of SUKL (State Institute for Drug Control).

\section{MATERIALS AND METHODS}

Nine healthy Merinolandschaf, aged about 4 years and free of infectious diseases, were used as experimental animals [11]. The sheep weight was between 76 and $97 \mathrm{~kg}$ (mean= $85.55 ;$ median $=81 ;$ mode $=78$ and 81$)$. They were all subjected to biochemical and hematological laboratory tests:

- Total protein, albumin, glucose, creatinine, urea, total bilirubin, aspartate amino transferase and gamma glutamyl transferase activities, $\mathrm{Na}, \mathrm{K}, \mathrm{Ca}, \mathrm{Cl}$, and $\mathrm{Mg}$ levels.

- Complete blood count and differential count of leukocytes.

- Thrombin, prothrombin time and fibrinogen coagulation blood test. 
After the clinical tests were done, the sheep were moved to the experimental department of the Clinic for Ruminant Diseases, at the University of Veterinary and Pharmaceutical Sciences Brno, for quarantine, to enable their adaptation and to control their health conditions on a daily basis [12]. The above mentioned clinical tests were performed also before the removal of the prosthesis. Examination of the results confirmed that the experimental animals were healthy and the selected parameters were within the normal range.

Animals were fed with meadow hay, ad libitum, augmented with a corn and vitaminmineral mixture.

In this study, 12 vascular prostheses with adiponectin and 6 control prostheses without adiponectin (commonly used in clinical practice) were implanted and subsequently removed in the following way:

First month (day 29, 34 and 35), 6 prostheses with adiponectin;

Third month (day 99, 99, 98, 99, 98, 93), 6 prostheses with adiponectin and 6 controls.

Antibiotics (Amoxicillin) were administered before surgery as a prophylactic, in accordance with the protected coagulum method. The antibiotics were continued for three days.

All sheep were fasted for 8 hours and were not allowed to drink for the 2 hours before anesthesia. The animals were premedicated with flunixin/meglumine $1.1 \mathrm{mg} / \mathrm{kg} /$ i.v. (Meflosyl, Fort Dodge Snímal Veterinaria), detomidin $0.02 \mathrm{mg} / \mathrm{Kg} / \mathrm{i} . \mathrm{m}$. (Domosedan, Pfizer), midazolam $0.2 \mathrm{mg} / \mathrm{kg} /$ i.v. (Dormicum, Roche). An $18 \mathrm{G}$ intravenous catheter (Vasofix, B.Braun) was inserted into the $v$ saphena with subsequent complete anesthesia with a bolus of ketamine $5 \mathrm{mg} / \mathrm{kg} /$ i.v. (Narketan, Vetoquinol). To facilitate intubation, propofol was slowly administered (Propofol $1 \%$, Fresenius Kabi) at a dose of 0.5$1 \mathrm{mg} / \mathrm{kg}$ until effect (diminished gag reflex and complete loss of jaw muscles tonus). Thereon, the sheep were intubated with a $11 \mathrm{~mm}$ endotracheal cannula. Once they were intubated, they were positioned in dorsal recumbence and connected to an inhalation device. General anesthesia was maintained using isoflurane (Aeran, Barter) with ETISO 1.2-1.4 volume percent. During anesthesia, sheep were ventilated using CMV with a tidal volume of $6-10 \mathrm{ml} / \mathrm{kg}$, PEEP up to $5 \mathrm{~cm} \mathrm{H}_{2} \mathrm{O}$, and PIP up to $20 \mathrm{~cm} \mathrm{H}_{2} \mathrm{O}$. Vital functions were monitored (Datex S/5, Datex-Ohmeda). Continuous infusions of crystalloid solutions (Ringer's solution, Barter's solution), at $10 \mathrm{ml} / \mathrm{kg}$ per hour, were administered perioperatively. Mean arterial pressure was maintained at above $75 \mathrm{~mm} \mathrm{Hg}$. To prevent the pressure from decreasing below this value, a continuous infusion of dobutamine (1-3 micrograms $/ \mathrm{kg} / \mathrm{min}$ ) was administered. The length of time from anesthesia to complete recovery did not exceed 60 minutes in any of the treated animals. The anesthesiology protocols for prosthesis implantation and extirpation were identical.

After wiping the dorsally recumbent animal with disposable drapes, surgical exposure of the tissue was performed to the right and left sides in front of the sternocleidomastoid 
muscle from a longitudinal incision above the trachea. The common carotid artery was carefully surgically exposed. Attention was focused on the separation from the nerve plexus, with special attention to the nvagus. After intravenous administration of heparin (about $10000 \mathrm{IU}$, according to the animal's weight), the carotid artery was closed with vascular clamps. A segment of about $10 \mathrm{~cm}$ of length of the right and left common carotid artery was replaced by the studied prosthesis.

All implanted vascular prostheses had a length of $10 \mathrm{~cm}$ and the implant lumen was always constant $(7 \mathrm{~mm})$. Since the 1950s it has been established that the length of the implant has to be at least $5.5-6 \mathrm{~cm}$. Otherwise tissue integration does not occur, as tissue integration is mainly the result of growth of cellular structures from the stump of the host's artery $[13,14]$.

Suture material Prolene 6-0 with a $13 \mathrm{~mm}$ needle (W 8706) was used. A continuous suture was performed. Edges of at least $2 \mathrm{~mm}$ were cut, both from the prosthesis and from the artery. End-to-end anastomoses were performed (Figure 1). After suturing the prostheses and careful hemeostasis, the platysma muscle and skin were sutured. Upon completion of the prosthesis suture, heparin was not neutralized with protamine sulphate and anticoagulation therapy was not administered after the operation.

When the surgical procedure was finished and the inhalation device was disconnected, sheep were moved to a post-surgery box and positioned sternally. Extubation was performed at the moment the swallowing reflex was recovered. Thereafter the sheep were continuously observed until complete recovery and restoration of all reflexes. Postoperatively, they were administered the analgesic flunixin/meglumine (Meflosyl, Fort Dodge Laboratories) in a dose of $1.1 \mathrm{mg} / \mathrm{kg}$ i.v. for three days.

The average anesthesia time for prosthesis implantation / explantation was $120+/-24$ minutes. The average surgical time for the implantation of the prosthesis was between 85 and 120 minutes, whereas for explantation the required time was between 60 and 120 minutes. Animals were followed up on a daily basis by a professional staff (veterinarians, veterinary technicians and keepers). When there were complications, head researchers were contacted to solve them.

A Doppler ultrasound examination was performed to verify the patency of each implanted prosthesis post-operatively and at monthly intervals (Figure 2).

In the experiment, tissue integration of the vascular prosthesis-implant was tested in the arterial system of sheep at an early time period (30 days) and a late one (100 days). In each case, the explanted prosthesis was analyzed macroscopically (Figures 3 and 4) and microscopically (Figures 5 to 8).

The animals were not sacrificed as from earlier experiments conducted by the first author on mouflons and other sheep breeds, one can assume that the absence of the carotid bed is not a life threatening condition for these animals.

The study was approved by the Ethical Committee of the University of Veterinary and Pharmaceutical Sciences Brno and followed all protocols according to law. In 
addition, all persons included in this experimental assessment were licensed for animal manipulation in experimental medicine, according to paragraph 17, article 1, of the Law 246/1992 Sb. for animal protection against tyranny.
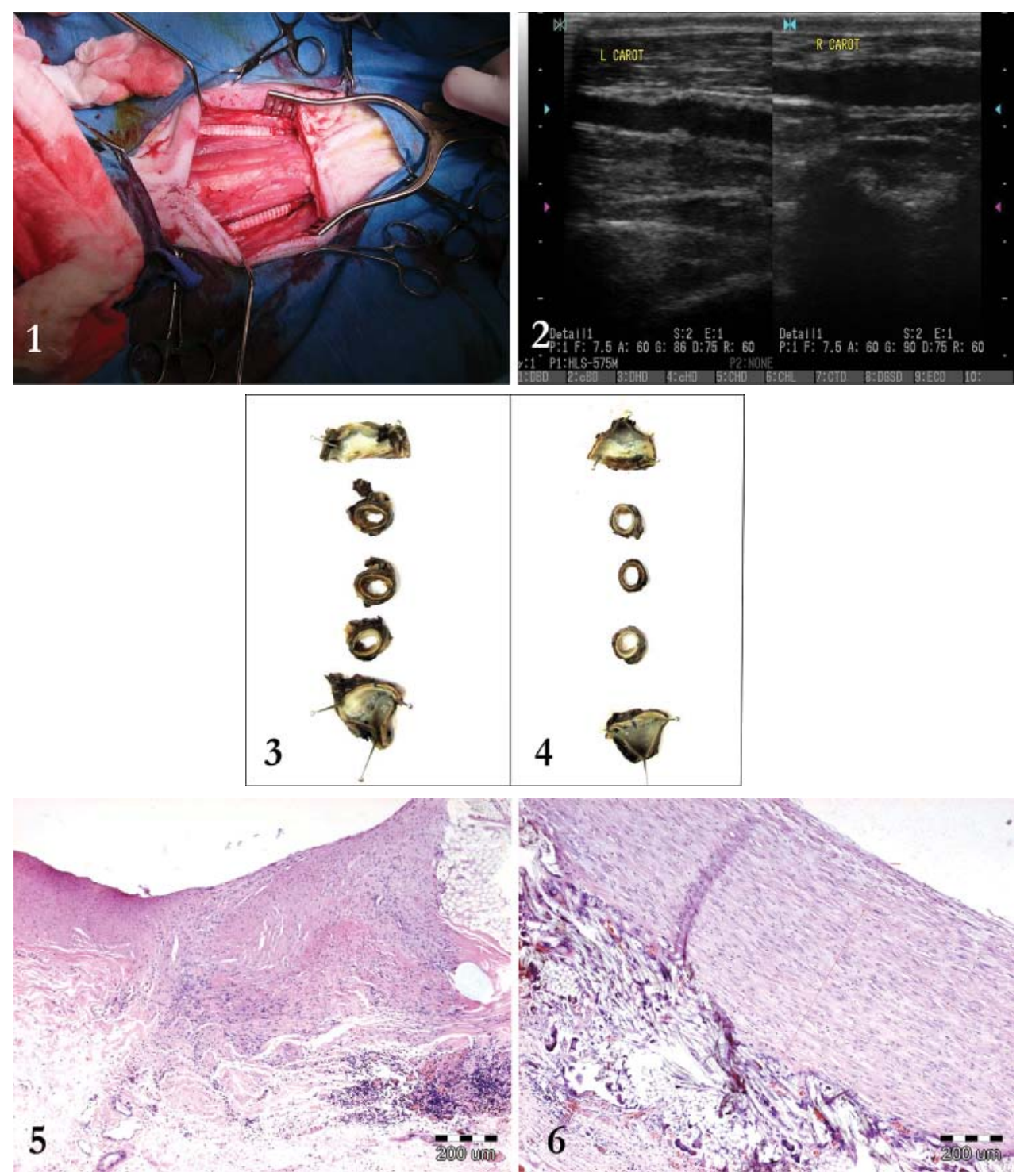

Figure 1. Bilateral vascular prostheses implantation - Sheep 1. Figure 2. Bilateral Doppler of RCCA and LCCA - 99 days after implantation - Sheep 1. Figure 3. Macroscopic view of implanted vascular prosthesis without adiponectin (Control group / LCCA) - Sheep 1. Figure 4. Macroscopic view of the implanted vascular prosthesis with adiponectin / RCCA - Sheep 1. Figure 5. Microscopic (histological) transverse view of the implanted prosthesis with adiponectin. Hematoxylin-Eosin. $40 \mathrm{X}$ - Sheep 1. Figure 6. Microscopic (histological) longitudinal view of the implanted prosthesis with adiponectin. Hematoxylin - Eosin. $40 \mathrm{X}$ - Sheep 1. 


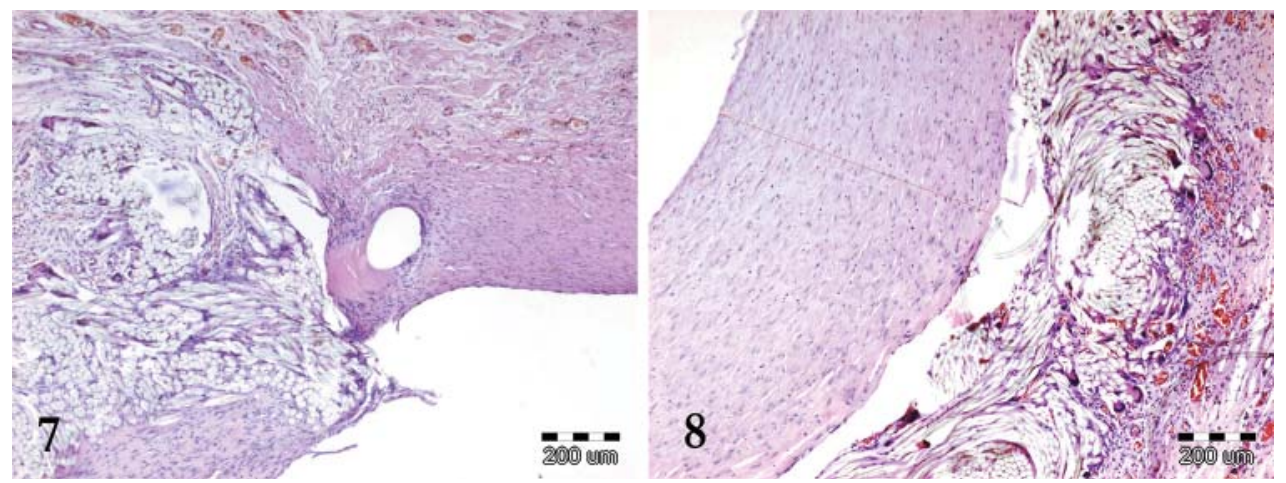

Figure 7. Microscopic (histological) transversely view of the implanted prosthesis without adiponectin (Control group). Hematoxylin - Eosin. $40 \mathrm{X}$ - Sheep 1. Figure 8. Microscopic (histological) longitudinal view of the implanted prosthesis without adiponectin (Control group). Hematoxylin - Eosin. $40 \mathrm{X}$ - Sheep 1.

\section{RESULTS}

Results are presented as follows:

Table 1 shows the operation protocol, the number of days with the implanted vascular prosthesis, and its patency.

All vascular prostheses implanted with and without adiponectin remained patent until the day of extirpation (see Figures 3 and 4). However, the vascular prostheses with adiponectin presented a faster and better healing. This was ascertained by histological methods (see Figures 5 to 8).

Figures 3 and 4 show the macroscopic view of the prostheses with and without adiponectin, in Merinolandschaf / Württemberger sheep number 1 (identification tag 18238, weight $94 \mathrm{~kg}$, aged 4 years).

The histological descriptions of the vascular prostheses, with and without adiponectin, were as follows:

Figure 5 shows a microscopic view of a prosthesis with adiponectin, with a pseudointima formation throughout the entire (100\%) lumen circumference. Having a thickness of $714 \mu \mathrm{m}$ and being partly epithelized, it corresponds to the late phase.

Figure 6 is a longitudinal view of the prosthesis with adiponectin, presenting a transversal cut of the anastomosis with adequate fibrous graft incorporation.

Figure 7 shows a microscopic view of the control prosthesis without adiponectin, with a pseudointima formation in just $50 \%$ of the lumen that is partly endothelised and $748 \mu \mathrm{m}$ thick.

In the rest of the lumen, there is a mural thrombus with a thickness of $382 \mu \mathrm{m}$. It corresponds to the organizational part of the late phase. 


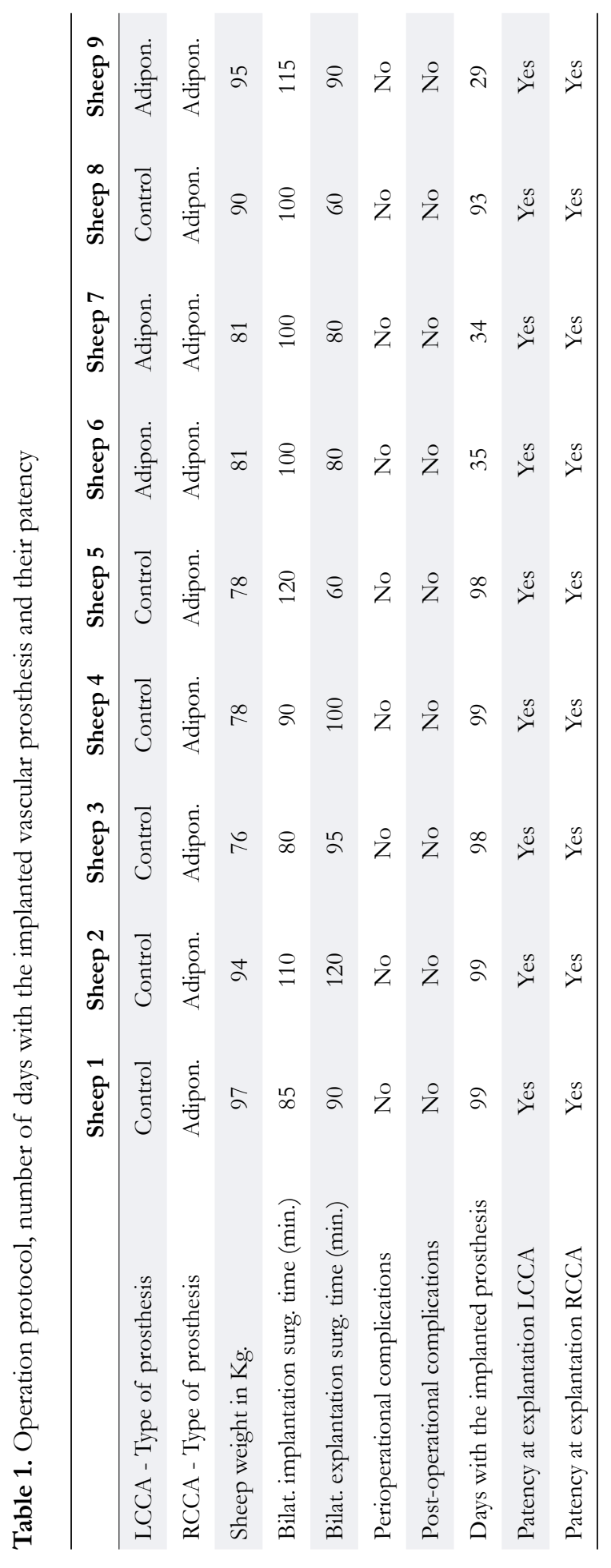


Figure 8 is a longitudinal view of the control prosthesis without adiponectin, presenting a transversal cut of the anastomosis with a satisfactory fibrous graft incorporation. The here described neointima is $677 \mu \mathrm{m}$ thick.

Some parts of all prostheses exhibit a well-developed external fibrous coating and properly formed fibers of refractive heterogeneous material with focal minor chronic inflammatory cellularity and scattered giant multinuclear cells around the fibers. In the pores of the prosthesis, there is a mature, well-vascularised granulation tissue with infrequent chronic inflammatory cells. There are also histiocytes and isolated neutrophils. The internal coating of the lumen (pseudointima) is formed by a relatively cellular connective tissue of a maximum thickness of $0.7 \mathrm{~mm}$ with fibroblasts and infrequent lymphocytes. Circumferentially, the pseudointima is endothelised. This corresponds to the late phase of graft incorporation. Within the artery-to-prosthesis transition, fibrous tissue integration with good graft incorporation was identified.

\section{DISCUSSION}

Before humans are subjected to clinical trials in relation to the development of a new vascular prosthesis it is necessary to assess rheological and immunological reactions to the prosthesis in a living animal, in vivo. It is still not possible to replace such experiments with in vitro methods. Therefore, it is still important to use animals in clinical trials.

Findings are of a relative value and there is still no guarantee they would be fully applicable to humans. Functionality of the vascular prosthesis can be deduced with great certainty, but the quality and speed of tissue integration cannot be completely evaluated, as cellular and extracellular activities differ in various animal species. Nevertheless it is evident that animal experiments preliminarily exclude inconvenient and incorrect technical procedures and sub-standard prosthetic implants.

The animals that were chosen to be the subject of the experiment were sheep, because of the following similarities of their carotid arteries with humans:

- Behavior of the arterial bed;

- Carotid length and accessibility;

- Endothelisation at anastomosis site.

Another advantage is that sheep require minimum care in the postoperative period and the follow- up is not too expensive [15].

Our results proved that vascular prostheses, coated on their inner surface with adiponectin, exhibited reduced thrombogenicity and improved patency, when compared with prostheses with no adiponectin. The researchers observed that none of the control vascular prostheses (without adiponectin), that are normally used in clinical surgery, did not obliterate, but the prostheses with adiponectin healed better and quicker. 
Histological results indicated a decreased formation of smooth muscle cells, thereby preventing narrowing of the lumen. It was clear that, in the case of the prosthesis coated with adiponectin, there was a better migration and proliferation of endothelial cells. Thus there was a faster and intact $(100 \%)$ endothelial layer formation around the prosthesis lumen, preventing platelet aggregation and so preventing the formation of a thrombus.

The researchers found that vascular prostheses coated with adiponectin improve the rheologic characteristics for healing. Evaluation was based on functionality, macroscopic and microscopic findings.

The differences in the time needed for the surgery depend on the surgeons' technique and skills. No perioperative and post-operative complications were observed.

In view of the fact that the experimental sample was very small, the results obtained cannot be taken as representative, but they do indicate that further research should be conducted into the field of vascular prosthesis for human use.

The results obtained indicated that vascular prostheses coated with adiponectin exhibited very good properties, i.e. no obliteration and quick healing, compared with those without it. Adiponectin has definite beneficial effects on vascular prosthesis patency. As this remains a promising vascular prosthesis, there is an incentive to do more research in order to go to step 2 clinical trials which will entail trials on humans.

\section{Acknowledgements}

This study was supported by the Ministry of Industry and Trade of the Czech Republic (Project: 2A - 1TP1/122). The authors would like to thank: University of Veterinary and Pharmaceutical Sciences Brno, for their technical contributions to the study. Assistant professor Karel Veselý, M.D., Ph.D., Department of Pathology, St. Anne's University Hospital, Faculty of Medicine, Masaryk University, Brno, Czech Republic, for the histological descriptions of the vascular prostheses.

\section{REFERENCES}

1. Bajaj M, Ben-Yehuda O: A big fat wedding - Association of adiponectin with coronary vascular lesions - Editorial comment. J Am Coll Cardiol 2006, 48:1163-1165.

2. Ouchi N, Shibata R, Walsh K: Cardioprotection by adiponectin. Trends of Cardiovasc Med 2006, 16:141-146.

3. Katagiri H, Yamada T, Oka Y: Adiposity and cardiovascular disorders - Disturbance of the regulatory system consisting of humoral and neuronal signals. Circ. Res 2007, 101:27-39.

4. Pischon T, Rimm E: Adiponectin: A promising marker for cardiovascular disease. Clin. Chem 2006, 52:797-799.

5. Schrer P, Williams S, Fogliano M, Baldini G, Lodish H: A novel serum-protein similar to C1q, produced exclusively in adipocites. J. Biol. Chem 1995, 270:26746-26749. 
6. Maeda K, Okubo K, Shimomura I, Funahashi T, Matsuzawa Y, Matsubara K: CDNA cloning and expression of a novel adipose specific collagen-like factor, apM1 (Adipose most abundant gene transcript 1). Biochem Biophys Res Commun 1996, 221(2):286-289.

7. Sawyer P, Modern vascular grafts, New York, USA, McGraw-Hill; 1986.

8. Podlaha J, Kořístek V, Černý J, Riebel O, Šilhart Z, Fiala J, Gregor Z: Experimental testing of new vascular prosthesis with small diameter. Skripta medica 1987, 60(4):235-242.

9. Podlaha J, Koř́istek V, Riebel O, Gregor Z, Šilhart Z, Fiala J, Pospíšil L, Černý J 1987, The influence of a modified external surface of the artificial prosthesis with small diameter on better biocompatible properties. Skripta medica 1987, 60 (8):471-474.

10. Walter M, Erasmi H, Schmidt R: A new biological vascular prosthesis. Vasa Suppl 1991, 33:90-91.

11. Enzler M, Zünd G, Schneider J: A new approach to in vivo testing of vascular grafts. Vasa 1994, 23(3):251-256.

12. Giardino R, Fini M, Rocca M, Nicoli N, Martini L, Giavaresi G, Di Paola M, Orienti L, Faggioli G, Gargiulo M: In vivo experimental research in vascular surgery. Methodology and current Italian law. Minerva Chir 1995, 50(6):613-619.

13. Krajíček M, Peregrin J, Roček M, Šebesta P: Chirurgická a intervenční léčba cévních onemocnění. Praha, Czech Republic: Grada Publishing; 2007, 115.

14. Firt P, Hejnal J, Vaněk I: Cevní chirurgie. Praha, Czech Republic: Avicenum; 1991, 24.

15. Krajíček M, Peregrin J, Roček M, Šebesta P: Chirurgická a intervenční léčba cévních onemocnění. Praha, Czech Republic: Grada Publishing; 2007, 116-117.

\title{
EKSPERIMENTALNA PROCENA NOVOG TIPA VASKULARNE PROTEZE SA ADIPONEKTINOM (ADIPOGRAFT Ra 1vk7/350) KOD OVACA
}

\author{
PODLAHA Jiř́, SCHWANHAEUSER Kräuff
}

Uprkos napretku medicine, razvoj idealne vaskularne proteze predstavlja značajan izazov. U ovoj studiji, obavljeno je testiranje i verifikacija karakteristika novog tipa vaskularne prosteze upotrebom adiponektina (Adipograft $\mathrm{Ra} 1 \mathrm{vk} 7 / 350$ ) koji je razvijen u Knitting istraživačkom institutu u Brnu. Dva tipa vaskularnih prosteza (12 sa adiponektinom i 6 kontrolnih, bez adiponektina) su implantirane u devet zdravih ovaca starih 4 godine, rase Merino. Implant, dužine $10 \mathrm{~cm}$ je implantiran u zajedničku karotidnu arteriju. Primenjena je teorija zaštićenog koaguluma pri čemu su ovce profilaktički primile antibiotsku terapiju. Pre završetka svake operacije, obavljen je Doppler U.S. u cilju verifikacije prohodnosti prosteze. Svaka je životinja posmatrana tokom celog trajanja studije, a prosteze su uklanjane 30. i 100. dana (posle jednog i posle tri meseca). Uočeno je da su sve prosteze koje su sadržavale adiponektin posle uklanjanja pokazivale prohodnost. Celokupnom dužinom, lumen implanta je bio veličine do 7 $\mathrm{mm}$. Histološkim ispitivanjem implantiranih prosteza, ustanovljeno je brzo i veoma 
kvalitetno zarastanje. Eksperimentalni rezultati ukazuju da su vaskularne prosteze obavijene adiponektinom uspešne sa stanovišta kliničke prakse. $\mathrm{Na}$ osnovu rezultata prohodnosti i brzine zarastanja, može da se zaključi da Adipograft Ra 1vk 7/350 može da predstavlja revoluciju u razvoju vaskularnih prosteza. 